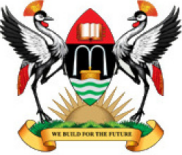

East African School of

Higher Education Studies \& Development
Makerere Journal of Higher Education

ISSN: $1816-6822 ; 4(2)$ (2013) $139-157$

DOI: http://dx.doi.org/10.4314/majohe.v4i2.2

(C) The Author(s) 2013

Reprints \& permission: EASHESD

http://ajol.info/majohe

\title{
Improving the Effectiveness of Public-Private Partnerships in the Provision of Higher Education in Uganda
}

\author{
Edris Serugo Kasenene ${ }^{1}$ \\ ${ }^{1}$ East African School of Higher Education Studies and Development, Makerere University [E- \\ mail:kserugo@yahoo.co.uk]
}

\begin{abstract}
The fundamental aim of forming a Public-Private Partnership (PPP) is to improve the provision of public services generally and in terms of quality and accessibility in particular. Unfortunately, realizing this aim as effectively as desired has eluded many countries in Sub-Saharan Africa. This has particularly been witnessed in the higher education sector. Despite the existence of PPPs in this sector, the quality and accessibility of higher education has continued to fall short of stakeholder expectations in many Sub-Saharan countries, including Uganda. This implies that the PPPs formed in this sector have largely been ineffective. Accordingly, this paper uses descriptive and factor analysis to explore the causes of such ineffectiveness and how they can be addressed to avert it. The paper is divided in four parts. The first part focuses on the methodology used to come up with the paper; the second part is on the effectiveness of the PPPs in terms of quality and accessibility of higher education; and the third part is about determinants of the infectiveness of the PPPs in Uganda's higher education. In the fourth part, recommendations for reform are suggested.
\end{abstract}

Keywords: Public-private partnership; NPM; Higher education reform.

\section{$1 \quad$ Introduction}

Public-Private Partnerships (PPPs) may be conceived of as cooperative ventures between the public and private sectors, formed from an amalgam of the resource capacity and expertise of each sector, in order to provide a stronger base for delivering defined public services in a better way (Nishtar, 2004). Effective PPPs are, therefore, bound to result into improved and more public services than would have been the case when the private and public sectors are working independently (Cheung, Chan and Kajewski (2009a); for they operate in a manner similar to the rationale of the Gestalt psychological principle that "the whole is more than the same of its parts" (Morgan, King, Weisz and Schopler, 1999). 
However, the situation in Sub Saharan Africa appears to be the direct opposite in spite of the existence of PPPs in this region. However, this paper concentrates on only two measures: quality and accessibility. This is because quite a number of African countries are still grappling with the challenge of achieving the desired effectiveness in terms of the quality and accessibility of the health, education, electricity, housing, and a host of other services and utilities delivered to the public (World Bank, 2008). In the education sector in particular, realizing these measures as desired in higher education is one of the critical challenges faced by most of these countries (World Bank, 2008). While sponsors of Sub Saharan higher education decry its quality in terms of failure to produce high level manpower skills and knowledge that relevant to underpinning the desired pace of socioeconomic development (Aliga, 2006); employers feel that it does not prepare its graduates enough to be in a position to effectively face the dynamic challenges and responsibilities of the workplace (Malick and Grisay, 2000). At the same time, higher education students express discontent about the instructional inadequacies with which they have to reckon in most of the Sub Saharan African institutions of higher learning (MunroeBlum, 2004). As well, a significant number of high school leavers intending to join higher education decry the limited intake capacity of these institutions because they deny them access to higher education (Bitamazire, 2008; Orszag and Kane, 2008).

This scenario continues to characterize African higher education even though many Sub Saharan countries have made attempts to establish Public-Private Partnerships (PPPs). In Uganda, for instance, PPPs were encouraged in higher education in the late 1990s (Bitamazire, 2008; Kayongo, 2007; Bogere and Nabiruma, 2009) when the government started to work together with private universities. However, little success has been achieved; the provision of higher education has continued to be devoid of the quality and accessibility expected by stakeholders. This portrays the PPPs in the higher education sector as having failed to achieve their anticipated effectiveness. It is against this background that this paper explores the factors explaining why this ineffectiveness exists, with the view to come up with ways through improvement might be made. Focus is on two measures, namely: quality and accessibility, because while different PPPs are formed to achieve different objectives, goals or targets, those in higher education tend to be established to improve the quality and accessibility of this education as the main objectives (Bitamazire, 2007).

\section{$2 \quad$ Methods}

Data were collected using two sets of questionnaires. One set measured determinants of the effectiveness of PPPs in higher education, and was administered to 40 key higher education officials that were purposively selected 
from the National Council of Higher Education, two private universities and two private tertiary institutions that were randomly selected. The second set, on the other hand, measured the quality of higher education delivered by the selected private institutions and was administered to a random sample of 123 students from these institutions. Informal interviews were also conducted with some of the selected key informants to get more information about some of the variables that were involved in the study.

\section{Correlates of the Effectiveness of PPP in Higher Education}

The available literature indicates that PPPs operate like any other organizational entity and to be effective, they require not only resources needed to facilitate their operations and functioning but also good management and planning as well as an enabling operating environment (Nishtar, 2004). If any of these factors is unfavourable, it is bound to constrain the effectiveness of PPPs as well. Important to note is that the constraining effect of each of the factors is expected to be minimized so as to maximize the intended PPP outcomes, if each of the partnering sectors fulfils its share of the obligations bestowed upon it by the partnership (Ibid). Therefore, if the effect is not minimized or if the extent of minimization is too negligible to bring about the desired level of the partnership outcome, it is in order to investigate the underlying causes. Since the results presented in the previous section revealed that this was the very situation characterizing the PPPs in Uganda's higher education sector, it was in order to establish the causes.

The causes were established after delving critically into the definition of a PPP. The definition cited earlier implies that a PPP is formed to provide a combined resource base and expertise aimed at improving or increasing levels of public service delivery. Expertise refers to the proficiency or skilled knowledge used to perform a task at the desired efficiency and effectiveness (Glen, 2006). In the PPP paradigm, neither the public nor the private sector can claim a monopoly supply of all the forms and types of expertise required to provide public services as desired (Wettenhall, 2007). The sectors therefore need each other. When each contributes the type or form of expertise that it possesses in form of working together as a partnership, the resultant amalgamated expertise is much better and yields greater outcomes in terms of public service delivery (Baker, 2003). In most PPPs, the public sector tends to contribute the required yet expensive technical expertise (Wamuziri and Clearie, 2005). The contribution tends to take the form of meeting the cost of hiring this expertise (Nisar, 2007).

In higher education, public sector expertise tends to be provided in form of planning the national framework for providing this education. This framework is meant to provide criteria for quality assurance, regulation, monitoring, and 
distribution of higher education in a country (Prabir, Bagchi and Seung-Kuk Paik, 2001). It also determines the minimum entry points that any applicant should have in order to be admitted into higher education (Jamali, 2007). Further, it sets the tuition structure which private higher educational service providers should adopt in order to provide the desired quality of education (Prabir, Bagchi and Seung-Kuk Paik, 2001). The public sector also provides expertise in form of hiring the skilled manpower needed to carry out the actual supervision and monitoring of the delivery of higher education for purposes of ensuring that educational services provided by institutions of higher learning conform to the set national standards (Ibid).

While the expertise provided by the public sector to determine quality standards for higher education and to enforce quality assurance through supervision and monitoring of this education has implications on the quality realized in this education, both the set minimum entry points and prescribed tuition structure have implications on the level of accessing this education. In general, literature indicates that the public sector can contribute to a PPP by availing the expertise needed to plan, supervise and monitor higher education in forming meeting the cost of hiring the required consultants, expatriates, professors, $\mathrm{PhD}$ holders, and other high calibre professionals. If the public sector or government fails in this regard, the partnership is adversely affected. Accordingly, a questionnaire administered to the selected officials included items that were intended to establish how Uganda's public sector performed in this regard. The analysis of the responses to the items led to results shown in Table 1.

Table 1: Expertise Contributed by Public Sector to PPPs in Uganda's Higher Education

\begin{tabular}{|c|c|c|c|c|c|}
\hline $\begin{array}{l}\text { Root Statement: The partnership between government and private } \\
\text { institutions of higher learning in Uganda is facilitated by the expertise } \\
\text { expected from the public sector in form of: }\end{array}$ & $\mathrm{N}$ & Min & Max & Mean & $\begin{array}{l}\text { Std. } \\
\text { Dev. }\end{array}$ \\
\hline $\begin{array}{l}\text { Setting the minimum standards for approving an institution of higher } \\
\text { education }\end{array}$ & 40 & 4 & 5 & 4.42 & 0.155 \\
\hline $\begin{array}{l}\text { Setting a framework for guiding regional distribution of higher } \\
\text { education }\end{array}$ & 40 & 1 & 4 & 1.85 & 1.096 \\
\hline $\begin{array}{l}\text { Enforcing standards for quality assurance management in higher } \\
\text { education }\end{array}$ & 40 & 1 & 2 & 1.74 & 1.081 \\
\hline $\begin{array}{l}\text { Determining funding structure that private institutions of higher } \\
\text { learning should follow when charging tuition to higher education } \\
\text { consumers }\end{array}$ & 40 & 1 & 4 & 3.51 & 0.098 \\
\hline Setting levels of tuition that higher education consumers can afford & 40 & 1 & 2 & 1.04 & 0.014 \\
\hline $\begin{array}{l}\text { Ensuring that higher educational services are brought nearer to their } \\
\text { consumers }\end{array}$ & 40 & 1 & 2 & 1.13 & 0.021 \\
\hline
\end{tabular}

Note: the indices were generated from the following codes: 1-Strongly Disagree, 2-Disagree, 3Not sure, 4-Agree, 5-Strongly Agree. The critical indicators of determinants are highlighted in bold letters. 
The mean responses in Table 1 show that respondents agreed without much deviation that the PPPs in Uganda's higher education are well facilitated by the public sector expertise of the form of setting the minimum standards for approving institutions of higher education (Mean $=4.42$, Std. $=0.155)$; and determining funding structure that these institutions should follow when charging tuition to higher education consumers (Mean $=3.51$, Std. $=0.098$ ). This is because the mean responses corresponding to these forms of expertise were close to '4', a code that represented 'agree' in the questionnaire. This implies that the public sector was doing well as far as its contributions of these forms to the PPP in Uganda's higher education were concerned. On the contrary, the mean responses further show that respondents disagreed without much deviation that the PPPs in Uganda's higher education were well facilitated by the public sector expertise of the form of enforcing standards for quality assurance management in higher education $($ Mean $=1.74$, Std. $=1.081)$; setting levels of tuition that higher education consumers can afford (Mean = 1.04, Std. = 0.014); setting a framework for guiding regional distribution of higher education $($ Mean $=1.85$, Std. $=1.096)$; and ensuring that higher educational services are brought nearer to their consumers $($ Mean $=1.13$, Std. $=$ 0.021).

The foregoing results imply that while the public sector was perceived as effective in setting standards for approving the worthiness of institutions of higher learning to provide the desired quality of higher education and while the sector was doing well in terms of determining funding a structure that private universities had to follow when charging tuition, it was ineffective in the areas of enforcing the set standards and of ensuring that the institutions charged tuition and fees that were affordable to higher education consumers. As argued earlier, the failure to enforce the set higher education standards compromises the effectiveness of the PPPs in terms of achieving the desired educational quality. At the same time, the failure to come up with a funding structure that is affordable to higher education consumers also renders the PPPs ineffective in terms of increasing accessibility to this education. For it effectively implies that the institutions are allowed to determine their own funding structures, which prevent some high school students from accessing higher education.

In an informal interview with the commissioner for higher education, it was discovered that the National Council of Higher Education (NCHE) was mandated by the Ministry of Education and Sports to set the national quality assurance criteria for determining the minimum educational standards. It was also found out that NCHE actually determined a funding structure that prescribes at least Uganda shillings nine million per student per semester if the institutions were to provide the desired quality of education. However, no institution could dare charge such exorbitant tuition as this would imply making access to higher education extremely difficult for many students. As shall be 
shown later, most of the students come from poverty-stricken backgrounds and all operators of higher education institutions are aware of this fact. Therefore, while allowing the institutions to charge their own tuition fees may have its own limitations to accessing higher education; it turns out to be a better option given that the tuition they charge is much lower than the recommended tuition. Lowering the tuition further to affordable levels requires the public sector to increase its role in the funding of higher education rather than pulling out of it altogether through the privatization policy recommended by the World Bank and IMF.

It is important to note that public sector expertise tends to focus on higher education more at national than at an institutional level (Musaazi, 2005). It is therefore not sufficient as far as delivering the desired quality and accessibility of higher education is concerned. It needs to be reinforced by private sector expertise whose main focus is at institutional level (Ibid). It has been observed that while private sector expertise can be a source of advising government on improvements needed in the delivery of higher education (Bogere and Nabiruma, 2009), it mainly focuses on planning for the production, maintenance, supportive, and managerial systems that make up and support the educational service delivery process at a school/institutional level (Musaazi, 2005). This indicates that private sector expertise concentrates on planning for actual provision of higher education.

Such planning is achieved through identifying and proposing the needed resources and infrastructure and how the resources can be mobilized to provide the desired quality and accessibility of higher education (Nabwire, 2008). The involved expertise focuses on carrying out institutional level programming and budgeting (Mordi, 2000). That is, coming up with programmes through which higher education can be delivered and the funding structure required to raise the resources needed to provide this education at the desired quality and accessibility. The conducted budgeting involves not only determining the instructional materials and physical infrastructure needed to provide the prescribed educational services to a specified number of students (Nabwire, 2008). It also focuses on proposing the tuition structure that can support an institution's efforts to effectively provide the desired quality and accessibility of education (Kayongo, 2007).

The foregoing observations suggest that private sector planning, programming, and budgeting expertise determines much of the intake capacity of higher education, and subsequently, its levels of quality and accessibility. The intake capacity tends to be determined in terms of student enrolment size admitted into institutions of higher learning (Buzindadde, 2000). However, while the size of student enrolment should ideally be determined based on the institutions' resource and infrastructural absorptive capacity (Ibid); many institutions in the developing world have tended to admit less or more than the 
optimum number of students, thereby compromising the optimal quality and accessibility of higher education (Le Wang, 2007). In fact, some institutions set higher while others lower than the nationally prescribed minimum points for admitting applicants into higher education. Practically, this has a dual effect on the quality and accessibility of higher education.

While institutions that set higher entry points may maintain their desired educational quality through admitting only the required number of students, they limit access to higher education since more students are left out (David, 2008). On the contrary, institutions that set lower entry points may compromise the quality of higher education by taking up more students than their intake capacity; but they increase accessibility to this education (Kahuku, 2008). It has also been observed that achieving the desired higher educational quality assurance through setting entry points has been compromised by the high demand for this education (Le Wang, 2007). Institutions of higher learning have been overwhelmed by large numbers of applicants, which have forced many of them to admit students beyond their intake capacity (Buzindadde, 2000). Consequently, most of the institutions have to work with the public sector if they are to maintain the desired quality in terms of expanding their educational infrastructure as desired. The formation of PPPs is thus viewed as a means through which the public sector can support the private sector to improve and increase quality and access to higher education.

Not only does private sector expertise focus on planning for institutions of higher learning. According to Gerhard and Gördel (2006), it also offers the managerial or administrative competence and internal control proficiency required to deliver quality higher educational services. The private sector has actually been observed to be more efficient at managing the public service delivery process (Nishtar, 2004). This is because it exercises better internal control in its endeavour to reach out to the grassroots so as to understand public service needs and to respond to the needs in an effective way (Fepuleai, 2007). It also tries to be cost efficient because it has to achieve desired business competitiveness and return on investment (Van Horne, 1996). All these advantages imply that the private sector tends to be better than the public sector at managing the delivery of public services. When such managerial proficiency is contributed in form of a partnership, it definitely has to result into better delivery of public services, particularly in terms of quality and accessibility. In the light of these observations, attempts were made to find out the extent to which the private sector had performed as a contributor to the PPPs in Uganda's higher education. Results are shown in Table 2. 
Table 2: Expertise Contributed by the Private Sector to PPPs in Uganda's Higher Education

\begin{tabular}{|c|c|c|c|c|c|}
\hline $\begin{array}{l}\text { Root Statement: The partnership between government } \\
\text { and private institutions of higher learning in Uganda is } \\
\text { well facilitated by private sector expertise of the form of: }\end{array}$ & $\mathrm{N}$ & Min & Max & Mean & $\begin{array}{l}\text { Std. } \\
\text { Dev. }\end{array}$ \\
\hline $\begin{array}{l}\text { Administrative competence needed to efficiently manage } \\
\text { the provision of education in institutions of higher } \\
\text { learning }\end{array}$ & 40 & 4 & 5 & 4.33 & 1.979 \\
\hline $\begin{array}{l}\text { Planning for the needed institutional physical educational } \\
\text { infrastructure }\end{array}$ & 40 & 1 & 2 & 1.28 & 0.902 \\
\hline Budgeting for the needed human resources & 40 & 1 & 2 & 1.30 & 0.887 \\
\hline $\begin{array}{l}\text { Budgeting for the material resources needed by the } \\
\text { institutions to provide the desired quality and } \\
\text { accessibility of higher education }\end{array}$ & 40 & 1 & 2 & 1.26 & 0.552 \\
\hline
\end{tabular}

Note: the indices were generated from the following codes: 1-Strongly Disagree, 2-Disagree, 3Not sure, 4-Agree, 5-Strongly Agree. The critical indicators of determinants are highlighted in bold letters.

Findings in Table 2 indicate that on average, respondents agreed without much deviation $($ Mean $=4.33$, Std. $=1.979)$ that the PPPs in higher education were well facilitated by private sector expertise of the form of administrative competence needed to efficiently manage the provision of higher education. On the contrary, the mean responses show that the respondents disagreed without much deviation that the PPPs were well facilitated by private sector expertise of the form of planning for the needed institutional physical educational infrastructure $($ Mean $=1.28$, Std. $=0.902)$; budgeting for the needed human resources $($ Mean $=1.30$, Std. $=0.887)$; and budgeting for the material resources needed by the institutions to provide the desired quality and accessibility of higher education $($ Mean $=1.26$, Std. $=0.552)$. These results indicate that the private was perceived as effective only in terms of providing administrative competence needed to manage higher education. It was not effective in terms of budgeting for the resources needed to provide the desired quality and accessibility of higher education. The ineffectiveness implies that the private sector had not done enough to ensure that higher education was provided at the desired quality and accessibility.

Apart from being cooperative sources of expertise, PPPs are also viewed as arrangements that create a stronger resource base for provision of public services (Prabir, Bagchi and Seung-Kuk Paik, 2001). This is because they combine the resources of both the public and private sectors to make a bigger pool that provides stronger support to the delivery of public services. The combined resources tend to take the form of human, material, financial and physical infrastructural resources (Jamali, 2007). In higher education, human resources include professors, $\mathrm{PhD}$ holders, and lecturers holding masters or bachelor's degrees (Roulla, 2002). Material resources take the form of instructional materials and facilities used by the lecturers to provide instruction 
and by students to learn as desired (Gwen, 2008; Tam Wai-Ming, 2008). Illustrations include library materials such as text and reference books, journals, manuscripts, computers, reading tables and chairs; lecture room facilities such as desks, seats, and laboratory materials such as science apparatus and chemicals (Roulla, 2002; Gwen, 2008). Physical infrastructural resources include the physical buildings established in form of classrooms, library, laboratory, and office buildings (Gibson and Brent, 2008).

PPPs ensure that the availability of each of the aforementioned resources is contributed by both the private and public sectors so as to improve, increase and maintain the desired quality and accessibility of higher education (Cheung, Chan and Kajewski, 2009a). Depending on the terms of the partnership, the public sector may contribute some of the resources in terms of tax concessions, paying salaries and allowances, building lecture rooms or providing block grants in form of supplementary finances or instructional materials (Gwen, 2008). The private sector tends to contribute land, buildings, instructional materials, and funds for administration and personnel welfare using the charged tuition and fees. Clearly, when each of the two partners makes good of their respective share of the partnership, the resultant pool is much greater and results into better quality and expanded accessibility of higher education. Thus, when the public or the private sector fails to honour its part of the partnership, ineffectiveness is bound to occur as this effectively means that less than the desired quality and accessibility of higher education will be realized. On the basis of these observations, attempts were made to establish the situation pertaining to the PPPs in this regard as far as Uganda's higher education was concerned.

Two main views were revealed by the officials about the resources contributed to the PPP between government and private institutions of higher learning in Uganda by both the public and private sectors. On the one hand, the responses indicated that the officials strongly agreed that the partnership was well facilitated by the mobilization of funds needed by the private sector to support provision of higher education. The officials also agreed that this partnership was well facilitated by prompt payment of human resources hired by the private sector to help in the delivery of higher education services. They also agreed that the PPP was well facilitated by government allocation of funds to hire human resources needed to plan for provision of higher education and to materially support the provision of this education.

In general, therefore, results in Table 6 imply that both the public and private sectors performed well on some indicators of mobilizing resources needed to support the effectiveness of PPPs in the provision of the desired quality and accessibility of higher education. However, the two sectors did not perform well on the indicators that were more critical to achieving the desired effectiveness of the PPPs. In particular, the private sector was ineffective not 
only in the mobilization of all the needed human resources but also in the establishment of the physical infrastructure and mobilization of all the instructional materials needed to facilitate the delivery of the desired quality and accessibility of higher education services. This was worsened by the failure of the public sector to promptly disburse or release the funds allocated to facilitate the PPPs in the delivery of the desired quality and accessibility of higher education. The public sector neither paid hired human resources promptly nor promptly disbursed the funds expected to materially support the provision of higher education. Accordingly, these results suggest that the ineffectiveness of the PPPs in Uganda's higher education is largely explained by government failure to promptly disburse the resources that it was expected to contribute towards supporting the partnership. The failure of the public sector to promptly release resources to the PPPs in higher education signifies lukewarm commitment of this sector to the partnership. This has been explained by Mwenda (2009) to be a consequence of the shift in government funding priorities caused by political ambitions and conditions imposed by the World Bank and International Monetary Fund.

Apart from the effects of how each of the partnering sectors fulfils its share on the effectiveness of PPPs in terms of bringing about the desired level of higher educational quality and accessibility, the operating environment is also an important factor in determining this effectiveness. This environment comprises the served consumers, input suppliers, competitors, and lenders (Hurst and Reeves, 2004). In higher education, such environment tends to be quite unpredictable because the influences of educational service consumers, input suppliers, lenders, competitors from other sectors, and other factors are extraneous to the control of these PPPs (Gwen, 2008).

In particular, while a PPP may agree to a funding structure needed to deliver the desired quality and accessibility of higher education, the structure may turn out to be quite unrealistic when viewed in the light of the ability of higher education consumers to pay the prescribed tuition (Stanislaw, 2008). The developing world generally and countries in Sub-Saharan Africa in particular are engrossed in high levels of poverty (World Bank, 2000). According to Mwenda (2009), the per capita income in most of the Sub-Saharan African countries is less than one dollar, implying that the majority of the people leave below the poverty line. Consequently, the majority of the consumers of higher education are bound to be poor people, implying that they may not be in a position to afford a funding structure set to facilitate the provision of the desired quality of education. Could this be true of Uganda?

As if that is not enough, most of the lenders in the developing world and in Sub Saharan Africa in particular, tend to offer unbearable lending terms (Kasibante, 2000). Not only do most commercial banks and other lending organizations offer loans at exorbitantly high interest rates; they also require 
expensive collateral yet give short grace periods and unrealistic loan repayment periods (Kaggwa-Pafula, 2000). Moreover, although PPPs can afford the collateral that the lenders require of borrowers (simply because of the presence of government), the terms of partnership do not permit them to offer security for the loans needed by the private partners so as to boost the capital base needed to provide the desired quality and accessibility of public services (Bohnstedt, 2000). Consequently, PPPs in Sub-Saharan Africa end up operating in conditions in which they have need more funds to provide the desired quality and accessibility of public services yet they cannot increase their capital base through taking up commercial loans. It may be argued that government can borrow the funds and increase its contribution towards the partnership but this argument is untenable in the light of the fact that even the public sector may make its initial contribution using borrowed funds (Martin, Reyna and Jorgensen, 2006).

The situation is aggravated by the fact that suppliers of higher educational inputs tend to offer the inputs at high prices, particularly in Sub Saharan Africa. This is because most of the higher education inputs are not manufactured locally but are imported from overseas countries. This implies that the prices of most of the inputs are sensitive to changes in foreign exchanges rates, which tend to be volatile in Sub Saharan Africa (Mutula, 2002). The inputs are also subject to all forms of import taxes such as custom duty and macroeconomic changes such as inflation (Ministry of Finance, Planning and Economic Development, 2007/08). All these factors plus the locally incurred costs (transport, storage, etc) and the margin of profit added by the suppliers make higher education inputs too expensive for the PPPs to ensure that they are as available in higher institutions of learning located in Sub-Saharan Africa as desired. This compromises the level of quality and accessibility realized by the institutions. In the light of these observations, attempts were made to establish how the operating environment of the PPPs in Uganda's higher education affected their effectiveness. Results are shown in Table 3.

Table 3: Effect of the Operating Environment of the PPPs in Uganda's Higher Education on their Effectiveness

\begin{tabular}{|c|c|c|c|c|}
\hline $\begin{array}{l}\text { Root Statement: The partnership between government and } \mathrm{N} \\
\text { private institutions of higher learning is well facilitated by: }\end{array}$ & Min & Max & Mean & $\begin{array}{l}\text { Std. } \\
\text { Dev. }\end{array}$ \\
\hline $\begin{array}{l}\text { Sponsors of higher education consumers who can afford the } 40 \\
\text { tuition and fees charged by the institutions of higher learning }\end{array}$ & 1 & 4 & 2.38 & 0.643 \\
\hline $\begin{array}{l}\text { Prompt payment of tuition and fees charged by institutions of } 40 \\
\text { higher learning higher education by private sponsors higher } \\
\text { education consumers }\end{array}$ & 1 & 2 & 1.63 & 0.555 \\
\hline $\begin{array}{l}\text { Affordable supply of inputs needed to support desired quality of } 40 \\
\text { higher education }\end{array}$ & 1 & 2 & 1.24 & 0.514 \\
\hline $\begin{array}{l}\text { A supportive commercial banking system in case the need for } 40 \\
\text { loan finance arises }\end{array}$ & 1 & 2 & 1.20 & 0.791 \\
\hline
\end{tabular}


The mean responses were close either to ' 1 ' or to ' 2 ', the codes for 'strongly disagree' and 'disagree', respectively. This indicates that on average, officials disagreed that the partnership between government and private institutions of higher learning was well facilitated by sponsors of higher education consumers who could afford the tuition and fees charged by the institutions of higher learning $($ Mean $=2.38$, Std. $=0.643)$. They expressed strong dissent to the idea that the partnership was well facilitated by prompt payment of the charged tuition and fees (Mean $=1.63$, Std. $=0.555)$; affordable supply of inputs needed to support desired quality of higher education (Mean = 1.24, Std. = 0.514); and by a supportive commercial banking system in case the need for loan finance arises $($ Mean $=1.20$, Std. $=0.791)$. This implies that the operating environment of the PPPs in Uganda's higher education was not supportive.

In general, results indicate that the public and private sectors in Uganda are not doing enough to make good of their respective contributions to the PPPs in higher education, particularly in terms of resource mobilization. The findings also show that all the components of the PPPs' operating environment are not supportive. It is therefore not surprising that the PPPs are ineffective and need to be improved. To establish areas that are critical to the effectiveness of these PPPs and to which attention needs to be focused, factor analysis was conducted (Table 4).

Findings in Table 4 show that five principle components were extracted from the responses to the determinants of the effectiveness of PPPs in Uganda's higher education. These were identified as: government funding, private sector funding, government expertise, private sector expertise, and the operating environment of the PPPs. A careful look at the reliability coefficients (Alpha values) indicates that they were all greater than 0.5 . This implies that all the components were reliable indicators of the determinants of this effectiveness. The cumulative variance indicates that the components explained up to $96.71 \%$ of the variation in determining the effectiveness of the PPPs. This implies that the components were responsible for much of the level of effectiveness registered these PPPs. The findings show further that individually, government funding was the most reliable (Alpha $=0.718$ ) determinant and one that explained the largest variation (Variance $=36.05 \%$ ) in the effect on the effectiveness of the PPPs. This was followed by private sector funding (Alpha $=0.619$, Variance $=27.34 \%$ ), then by expertise from government $($ Alpha $=$ 0.568 , Variance $=12.44 \%$ ) and then by private sector expertise (Alpha $=0.523$, Variance $=10.54 \%$ ). The operating environment followed with a reliability coefficient of 0.503 and explained variance of $10.33 \%$. These findings show that although the effectiveness of the PPPs is determined by the nature of all the five components, it is more influenced by government funding. Thus, government funding needs to be improved if the effectiveness of the PPPs is to be achieved as desired. 
Table 4: Determinants of the Effectiveness of PPPs in Higher Education

Root Statement: The partnership between government and private institutions of higher learning is well facilitated by the:

Prompt disbursement of sub

institutions of higher learning

Prompt release of funds expected from government to materially support the provision of higher education by private institutions of higher learning

Allocation of funds expected from government to help lower the tuition that would have been charged to higher education consumers

Allocation of funds expected from government to materially support the provision of higher education by private institutions of higher learning

Allocation of funds expected from government to hire human resources needed to plan for provision of higher education in Uganda

Prompt payment of people hired by government to help in the delivery of higher education

Government hiring of expert inspection and monitoring of private institutions of higher learning

to ensure set national quality standards are followed by institutions of higher education

Funding structure set by private institutions to support provision of education

Educational facilities and equipment mobilized by the private sector to support the provision of

the desired quality of higher education

Mobilization of funds by private sector to support provision of higher education

Hiring human resources needed to deliver higher education

Prompt payment of human resources employed by the private sector to help in the delivery of

higher education services

Establishing of physical infrastructure needed to facilitate the delivery of higher education

Government expertise of the form of setting the minimum standards for approving an acceptable

funding .910

.902

.816

.770

.666

.606 9

institution of higher education

Government expertise of the form of setting a framework for guiding regional distribution of

Private sector Gov't

Private sector expertise expertise

Operating environment 
higher education

Expertise expected from government in terms of enforcing standards for quality assurance

Expertise from government in terms of determining funding structure that private universities

should follow when charging tuition to higher education students

Expertise from government in terms of setting levels of tuition affordable to students

Expertise expected from government in terms of ensuring that higher educational services are

brought nearer to their consumers

Private sector expertise in terms of administrative competence needed to efficiently manage the

provision of education in institutions of higher learning

Expertise expected from the private sector in terms of planning for the needed institutional

physical educational infrastructure

Private sector expertise in terms of budgeting for the needed human resources

Private sector expertise in terms of budgeting for the material resources needed by institutions of

higher learning to provide the desired quality of education

Sponsors of higher education consumers who can afford the tuition and fees charged by the

institutions of higher learning

Prompt payment of tuition and fees charged by institutions of higher learning higher education by

private sponsors higher education consumers

Affordable supply of inputs needed to support desired quality of higher education

A supportive commercial banking system in case the need for loan finance arises

Alpha

$\%$ Variance Explained

$\%$ Cumulative Variance Explained

Extraction Method: Principal Component Analysis. Rotation Method: Varimax with Kaiser Normalization 
A careful scrutiny of the factor loadings reveals to most of the selected officials, prompt disbursement of subsidies expected from government as supplementary budget to private institutions of higher learning as the best indicator of public sector funding as a determinant of PPP effectiveness (Factor Loading $=0.910)$. Similarly, they showed that the funding structure set by private institutions to support provision of higher education was the best indicator of private sector funding (Factor Loading $=0.741$ ). Further, setting the minimum standards for approving an institution of higher education as acceptable was the best indicator of public sector expertise as a determinant (Factor Loading $=0.733$ ); yet administrative competence needed to efficiently manage the provision of education in institutions of higher learning was the best indicator of private sector expertise (Factor Loading $=0.651$ ). The best indicator of the operating environment of the PPPs was revealed as the affordability of sponsors of higher education consumers to pay the tuition and fees charged by the institutions of higher learning (Factor Loading $=0.738$ ).

\section{$4 \quad$ Conclusions and Recommendations}

Findings show that although the ineffectiveness of the PPPs was explained by less supportive private sector funding, un-enforced government expertise, inadequate private sector expertise, and unsupportive operating environment, it was more explicated by poor government funding. The findings show promptness in government disbursement of subsidies to private institutions of higher learning was the most critical explanatory factor followed by the inadequate internal funding structure of these institutions, un-enforced standards set by government to approve of the institutions, and the failure of private higher education sponsors to afford the charged tuition and fees. The results therefore show that the desired effectiveness of the PPPs can be achieved by addressing each of these problems. Against this background, the following recommendations are made:

1) The government of Uganda should ensure that it promptly disburses the subsidies expected from it as supplementary budget to private institutions of higher learning.

2) Institutions of higher learning in Uganda should improve their internal funding structure not by increasing tuition and other fees but by negotiating with government to increase its funding to higher education and to release the allocated funds promptly

3) The government should not stop at setting quality assurance standards but should also enforce their observance by the private institutions of higher learning. 
4) The private sector should ensure that it mobilizes all the human and instructional resources needed to provide the desired quality and accessibility of higher education. This can be achieved if recommendations (1) and (2) above are adopted.

5) Government should improve the household incomes of the private sponsors of higher education through effective implementation of its poverty eradication programmes such as Bonnagaggawale. This will improve the affordability of higher education in terms of cost.

\section{References}

Aliga, A. (2006). Impact of Government Funding on University Management, The Monitor, March, p. 18.

Baker, C. R. (2003). Investigating Enron as a public private partnership, Accounting, Auditing \& Accountability Journal, 3 (16) 12-27, accessed on $12^{\text {th }}$ May 2009 at http://www.emeraldinsight.com.

Bitamazire, G.N. (2008). Ministerial Statement presented to Parliament by the Minister of Education. Kampala: MOES.

Bohnstedt, A. (2000). (Ed). Recent developments in Uganda's Finance sector: Crisis of transition? FSD Series No.3, Kampala: Bank of Uganda

Bogere, H., \& Nabiruma, D. (2009). Four universities to be shut down. The Observer, p. 13-14.

Buzindadde, T. M. (2000). The influence of increased enrolment on lecturerstudent interaction at Makerere University. Makerere University: Unpublished M. ED Dissertation.

Cheung, E., Chan, A. P.C., \& Kajewski, S. (2009a). Reasons for implementing public private partnership projects: Perspectives from Hong Kong, Australian and British practitioners, Journal of Property Investment \& Finance, 1 (27) 19-33, accessed on $5^{\text {th }}$ July 2009 at http://www.emeraldinsight.com.

Cheung, E., Chan, A. P.C., \& Kajewski, S. (2009b). Enhancing value for money in public private partnership projects: Findings from a survey conducted in Hong Kong and Australia compared to findings from previous research in the UK, Journal of Financial Management of Property and Construction, 1 (14) 12-22, accessed on $12^{\text {th }}$ May 2009 at http://www.emeraldinsight.com.

Cox, A. (2000). Funding agency contribution to education for all. London: Oxford Publishers.

David H. M. (2007). Modern Conceptions of Educational Quality and State Policy Regarding Small Schooling Units, accessed on $7^{\text {th }}$ July 2009 at http://eric.ed.gov/ERICWebPortal/Home. 
Fepuleai, S. M. (2007). Quality assurance of school education and training in Samoa, accessed on $2^{\text {nd }}$ July 2009 at http://www.apqn.org/events/past/details/102/ presentations/files/19_fepulai_sinapi_moli.pdf.

Gerhard, H. S., \& Gördel, B. (2006). Quality Assurance in the German School System, European Educational Research Journal, 3 (5) 196-209, accessed on $5^{\text {th }}$ July 2009 at http://dx.doi.org/10.2304/.

Gibson, H., \& Brent, D. (2008). The impact of Public Private Partnerships on education: A case study of Sewell Group Plc and Victoria Dock Primary School, International Journal of Educational Management, 1 (22) 28-43, accessed on $12^{\text {th }}$ May 2009 at http://www.emeraldinsight.com.

Glen, C. (2006). Key Skills Retention and Motivation: The War for Talent Still Rages and Retention is the High Ground, Journal of Industrial and Commercial Training 1 (38) 37-45, accessed on $17^{\text {th }}$ January 2009 at http://www.emeraldinsight.com.

Gwen, H. (2008). Developments in the public-private partnership funding of Scottish schools, Journal of Applied Accounting Research, 2 (9) 18-34.

Hurst, C., \& Reeves, E. (2004). An economic analysis of Ireland's first public private partnership, International Journal of Public Sector Management, 5 (17) 44-55, accessed on $12^{\text {th }}$ May 2009 at http://www.emeraldinsight.com.

Ibrahim, A. D., Price, A .D. F., \& Dainty, A. R. J. (2006). The analysis and allocation of risks in public private partnerships in infrastructure projects in Nigeria, Journal of Financial Management of Property and Construction, 3 (11) 55-70, accessed on $12^{\text {th }}$ May 2009 at http://www.emeraldinsight.com.

Jamali, D. (2007). A study of customer satisfaction in the context of a public private partnership, International Journal of Quality \& Reliability Management, 4 (24)17-34, accessed on $5^{\text {th }}$ July 2009 at http://www.emeraldinsight.com.

Joshi, P. L., Al-Mudhaki, J. \& Bremser, W. (2003). Corporate Budget Planning, Control and Performance Evaluation in Bahrain, Managerial Auditing Journal, 9, 18, accessed on 12th May 2008 at http://www.emeraldinsight.com.

Kahuku, C. (2008). School-based managerial challenges of universal primary education in selected primary schools of Kabale municipal town, Uganda, Kampala International University: Unpublished M. Ed. Dissertation.

Kasibante, M. (2000). Interest rates for the Micro finance banker, 1, 1, June

Kayongo, P. (2007). Financing and Quality of Education in Institutions of Higher Learning, Journal of Bankers 2, 5, 79-89.

Le Wang (2007) Quality-Quantity Trade-off in China: Using One-Chile Policy as a Natural Experiment, accessed on $17^{\text {th }}$ June 2009 at http://www.wise.xmu.edu.cn/panel2007/paper/WANG(Le).do. 
Malick, L., \& Grisay, A. (2000). The Quality of Education in Developing Countries: A Review of some Case Studies and Policy Documents. Paris International Institute for Educational Planning. UNESCO.

Martin, A., \& McBoyle, G. (2006). Scotland's Malt Whisky Trail: Management issues in a public-private tourism marketing partnership, International Journal of Wine Marketing, 2 (18) 6-21, accessed on $5^{\text {th }}$ July 2009 at http://www.emeraldinsight.com.

Martin, M.P., Reyna, M. M., \& Jorgensen, A. (2006). Loan Portfolio Management, accessed on $1^{\text {st }}$ July 2009 at http://www.fca.gov/Download/lpmfortheweb.pdf.

Ministry of Education and Sports (2003). National Policy on Public Private Partnership in Education. Kampala: Ministry of Education and Sports.

Ministry of Education and Sports (2007). Public-private partnerships in Education: Increasing private sector participation in all aspects of the National Education Programmes, http://www.education.go.ug/part_education.htm.

Ministry of Finance, Planning and Economic Development (2007/08). Background to the Budget. Kampala: MFPED.

Mordi, S. E. O. (2000). Budgeting and Financial Management, The Delta Bureaucrat: A Quarterly Magazine, 1, 1, 12-31.

Morgan, C. T., King, R. A., Weisz, J. R., \& Schopler, J. (1999). Introduction to psychology $\left(11^{\text {th }}\right.$ ed). New York: McGraw-Hill Book Company.

Munroe-Blum, H. (2004). Universities at a Crossroads, Speech Delivered to the Canadian Club of Montreal. Accessed on 25th May 2009 at http://www.mcgill.ca/principal/speeches/crossroads/.

Mutula, S. M. (2002). University education in Kenya: current developments and future outlook, International Journal of Educational Management, 3, 16, accessed on 12th May 2008 at http://www.emeraldinsight.com.

Musaazi, J. C. S. (2005). Educational Planning: Principals, Tools and Applications in the Developing World. Kampala: Makerere University.

Mwenda, A. (2009). Analysis of the Public Service Sector in Uganda, The Independent, January.

Nabwire, A. (2008). Budget management and educational service quality at Kyambogo University, Uganda Management Institute: Unpublished MBA Dissertation.

Nisar, T. M. (2007). Value for money drivers in public private partnership schemes, International Journal of Public Sector Management, 2(20) 32-45, accessed on $12^{\text {th }}$ May 2009 at http://www.emeraldinsight.com

Nishtar, S. (2004). Public-private partnerships in health-a global call to action. Accessed on $19^{\text {th }}$ June 2009 at http://health- policysystems.com/content/2/1/5. 
Okwakol, M. (2005). Budget Reforms and Service Delivery in the Public Sector: A case of Selected Government Ministries. Makerere University Business School: Unpublished MBA Dissertation.

Orszag, P. R., \& Kane, T. J. (2008). Funding Restrictions at Public Universities: Effects and Policy Implications Education, accessed on $23^{\text {rd }}$ May 2009 at http://www.brookingsedu/papers/2008/0910education_kane.pdf

Prabir, K., Bagchi, J., \& Seung-Kuk Paik, L. (2001). The role of public-private partnership in port information systems development, International Journal of Public Sector Management, 6 (14) 42-66, accessed on $5^{\text {th }}$ July 2009 at http://www.emeraldinsight.com.

Roulla, H. (2002). Globalization, university transformation and economic regeneration: A UK case study of public/private sector partnership, International Journal of Public Sector Management, 2 (15) 12-22, accessed on $5^{\text {th }}$ July 2009 at http://www.emeraldinsight.com.

Scott, P. (2005). Access to Education: The Case for Public Universities, accessed on $19^{\text {th }}$ June 2009 at http://www.kingston.ac.uk/vc-office/.

Stanislaw, B. (2008). A partnership of public and private sectors as a model for the implementation of urban revitalization projects, Journal of European Real Estate Research, 1 (2) 8-19, accessed on 12 ${ }^{\text {th }}$ May 2009 at http://www.emeraldinsight.com.

Tam Wai-Ming, F. (2008). The Management of Education Quality: Comparison of Competing Perspectives, accessed on $6^{\text {th }}$ March 2009 at http://sunzi1 .lib.hku.hk/hkjo/view/33/3300.

Van Horne, J. C. (1996). Financial Management and Policy (8th Ed) New Jersey: Prentice Hall.

Wamuziri, S. C., \& Clearie, A. G. F. (2005). Economic feasibility of the proposed Second Forth Road Bridge using Public Private Partnership procurement, Journal of Financial Management of Property and Construction, 2 (10) 19-31, accessed on $12^{\text {th }}$ May 2009 at http://www.emeraldinsight.com.

Wettenhall, R. (2007). Is ActewAGL a genuine public-private partnership? International Journal of Public Sector Management, 5 (20) 20-32, accessed on $7^{\text {th }}$ July 2009 at http://www.emeraldinsight.com.

World Bank (2000). Development indicators of public expenditure in the developing world, Washington D.C.: World Bank.

World Bank (2008). Progress of higher education in the developing world, Washington D.C.: World Bank. 
